Research Article

\title{
Evaluation of Effect of Katupila Arka in Post-Operative Fistulotomy wound Management: A Case Report
}

\author{
KM Sweta', Ashwin Jayaram Shetty ${ }^{2}, \underline{P \text { Bhat Ramesh }}{ }^{3}$
}

${ }^{1}$ Associate Professor, ${ }^{2}$ PG Scholar, ${ }^{3}$ H.O.D and Principal, Department of Shalya Tantra PG Studies, Sri Sri College of Ayurvedic Science and Research Hospital, Bengaluru, Karnataka.

DOI: https://doi.org/10.24321/2394.6547.201909

\section{I $\quad \mathbf{N} \quad \mathbf{F} \quad \mathbf{O}$}

\section{Corresponding Author:}

Ashwin Jayaram Shetty, Department of Shalya Tantra PG Studies, Sri Sri College of Ayurvedic Science and Research Hospital, Bengaluru, Karnataka.

E-mail Id:

ashwinjayaramshetty@gmail.com

Orcid Id:

https://orcid.org/0000-0002-7240-3461

How to cite this article:

Sweta KM, AJ Shetty, Ramesh PB. Evaluation of Effect of Katupila Arka in Post-Operative Fistulotomy wound Management: A Case Report. J Adv Res Ayur Yoga Unani Sidd Homeo 2019; 6(3\&4): 14-16.

Date of Submission: 2020-01-20

Date of Acceptance: 2020-02-08

\section{$\begin{array}{llllllll}\mathbf{A} & \mathbf{B} & \mathbf{S} & \mathbf{T} & \mathbf{R} & \mathbf{A} & \mathbf{C} & \mathbf{T}\end{array}$}

Introduction: Securinega leucopyrus Muell. is known as Humari in India, Katupila in Sri Lanka and Spinous fluggea in English. It is a desert climatic plant used topically in paste form for healing of acute, chronic and non-healing wounds as a folklore practice in Sri Lanka. The aim of this study is to evaluate the role of Katupila Arka in the management of post-operative wound of fistulotomy.

Methodology: It is a case report of a 42 years old male patient who presented with the chief complains of swelling around the anal region associated with pain and pus discharge. On examination, it was diagnosed as subcutaneous low-level fistula. Hence, he was treated by fistulotomy under local anesthesia. The wound was dressed with Katupila Arka twice daily for 1 week and once daily for a period of 14 days.

Result: Complete healing of the post-operative wound was observed in 3 weeks period without any complications.

Discussion: Post-operative fistulotomy wound is a contaminated wound and is more prone to get further contamination by feces, which may lead to secondary infections or delayed wound healing. So, management of such wounds is a challenging task. In the present case, Katupila Arka has shown promising results in successful management of the post fistulotomy wound with ease and devoid of any complications. Further clinical study is needed to evaluate the effectiveness in larger sample.

Keywords: Securinega leucopyrus Muell., Katupila, Spinous Fluggea, Arka, Fistulotomy, Wound, Contaminated Wound, Non-Healing Wound, Dressing

\section{Introduction}

Fistulotomy is one among the surgical procedure used to treat fistula, ${ }^{1}$ which leaves the patient with secondary healing of the post-operative wound. Managing these wounds has been a challenging task, as it gets very less resting period and is more prone to get contaminated by feces, which hinders wound health and delays wound healing. Thus, these wounds are classified under the 
category of contaminated wounds. ${ }^{2}$ Securinega leucopyrus Muell. is known as Humari in India, Katupila in Sri Lanka and Spinous fluggea in English. It is a plant which grows in desert and is used topically as paste as a cure for acute, chronic and non-healing wounds as a traditional practice in Sri Lanka. ${ }^{3,4}$ This drug is easily available in Sri Lanka and has been used for various disorders. Pharmacognostic study of Katupila shows the presence of calcium oxalate, tannin and oil which is necessary for wound healing. ${ }^{3,4}$ In Ayurveda, Acharya Sushruta has described Shashti Upakramas ${ }^{5}$ for comprehensive management of Vrana (wound). This shows the importance of local application of different drugs. Hence, this case study was undertaken to evaluate the role of Katupila in the form of Arka in the management of post-operative fistulotomy wound. For the study, the drug was procured from an authentic source in Sri Lanka and the Arka was prepared by classical distillation method and was stored in a glass container in a cool and dry place.

\section{Case Report}

A 42 years old male patient with no significant medical history, presented with the chief complains of swelling around the anal region associated with pain and pus discharge. On examination, a low-level fistula with external opening at 6 o'clock position, about $3 \mathrm{~cm}$ from the anal verge, was observed. Digital rectal examination revealed internal opening at 6 o'clock position at the level lower $1 / 3^{\text {rd }}$ of anal canal. Hence, it was diagnosed as subcutaneous lowlevel fistula. Study was done after obtaining an informed consent from the patient.

\section{Intervention}

He was treated by fistulotomy under local anesthesia. The wound was dressed with sterile gauze soaked in Katupila Arka twice daily for 1 week and once daily for a period of 2 weeks. Patient was observed for a period of 3 weeks.
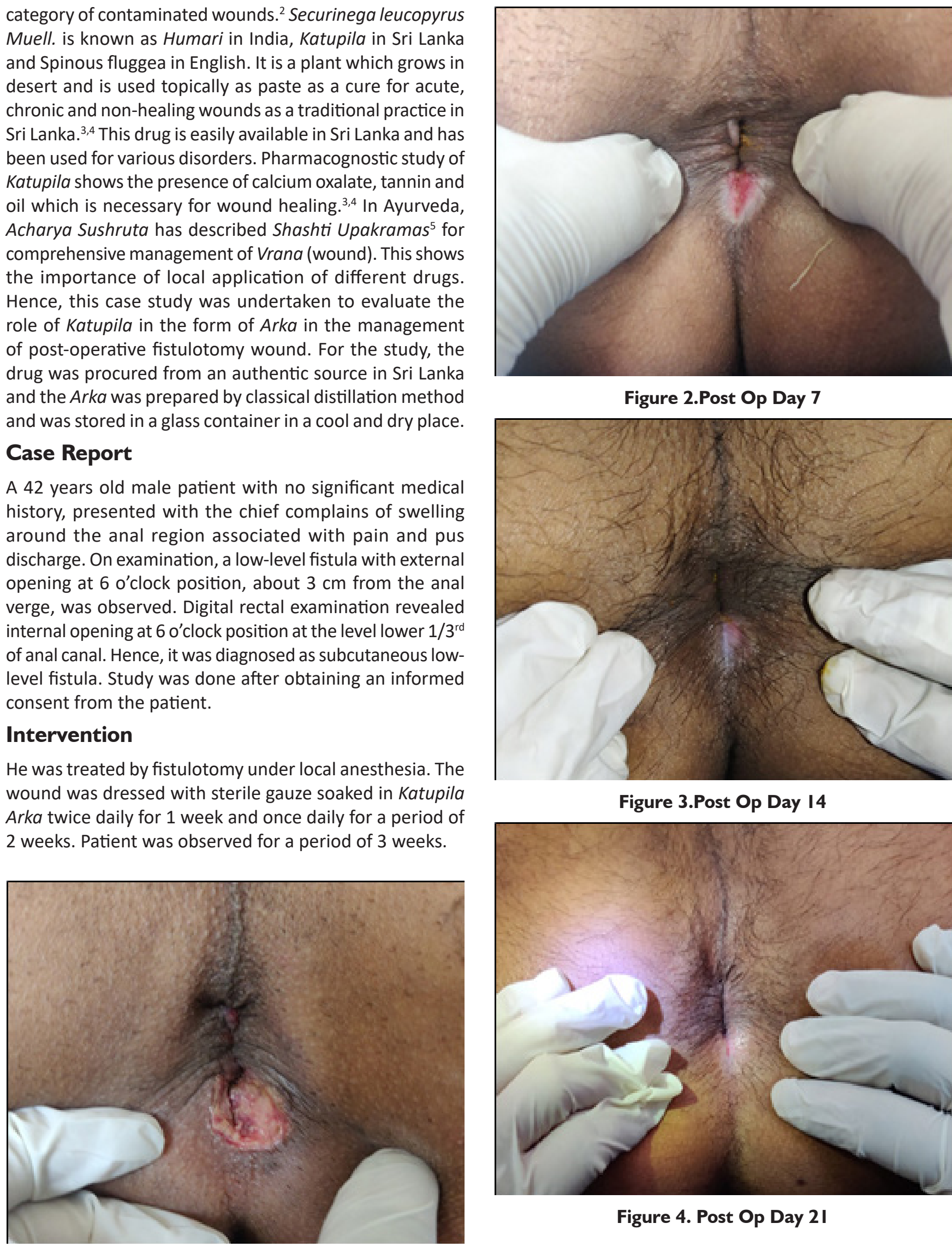

Figure 2.Post Op Day 7

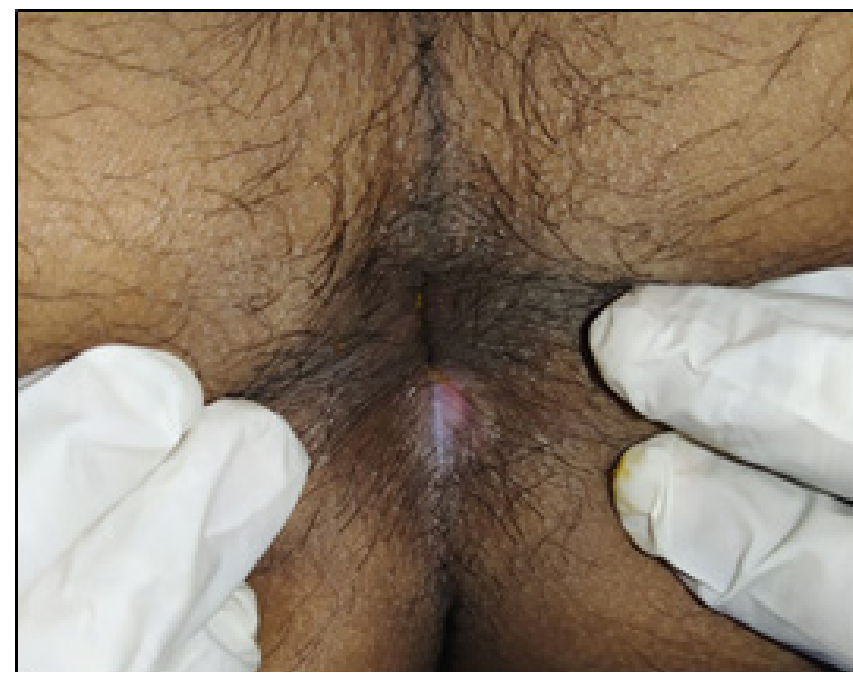

Figure 3.Post Op Day I4

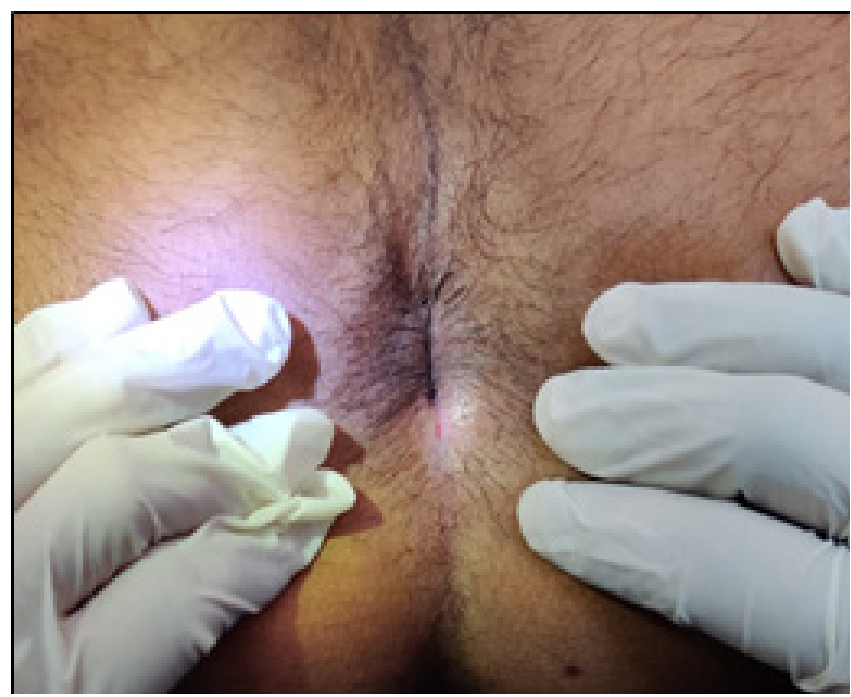

Figure 4. Post Op Day 21

Figure I.Post Op Day I 


\section{Result}

It was observed that the wound was completely healed in 3 weeks period, without any complications and with minimal scarring.

\section{Discussion}

Post-operative fistulotomy wound is a contaminated wound and is more prone to get further contamination by feces, which may lead to secondary infections or delayed wound healing. So, management of such wounds is a challenging task. In the present case, Katupila Arka has shown promising results in successfully managing the post-operative fistulotomy wound with ease and devoid of any complications. Katupila possesses Kashaya and Tikta Rasa; Lagu, Ruksha, Tikshna Gunas; Ushna Veerya, Katu Vipaka and exerted Lekhana action and thus, helped in removing the debris and unhealthy tissue and slough. ${ }^{3,4}$ In a week's period, sloping edge and healthy granulations were appreciated and the discharge from the wound was also scanty. The antioxidant activity due to the presence of flavonoids and tannins in abundance in Katupila, it has proven to promote wound healing. ${ }^{6}$ It is also found to be cost effective, safe and easy to apply.

\section{Conclusion}

As per the folklore practice, Katupila is used in the form of Kalka for the management of diabetic ulcers. ${ }^{3,4}$ Preparing $K a l k a$ on a daily basis is not an easy task. Thus, coming up with a better option like Arka which is easy to prepare and can be preserved for a much longer duration, would make its applicability easier and, as it will contain the active principles of the drug, we can expect it to have better results. In the present case, Katupila Arka has shown promising results in challenging conditions like a contaminated post-operative fistulotomy wound. Thus, it can be stated that Katupilla Arka is effective in the management of post-operative fistulotomy wound. Further clinical study may be needed to evaluate the effectiveness in larger sample.

\section{Conflict of Interest: None}

\section{References}

1. Sriram, Bhat M. SRB's Manual of Surgery. Jaypee, The Health Science Publisher. 2016; 1055. Available from: http://postgraduatebooks.jaypeeapps.com/pdf/ Surgery/Srb's_Manual_Of_Surgery.pdf.

2. Sriram, Bhat M. SRB's Manual of Surgery. Jaypee, The Health Science Publisher. 2016; 3.

3. Dudhamal T, Gupta S, Mahanta V, Ajmeer A. Katupila Securinega leucopyrus as a potential option for diabetic wound management. Journal of Ayurveda and Integrative Medicine 2014; 5(1): 60. Available from: https://www.ncbi.nlm.nih.gov/pmc/articles/ PMC4012365/.
4. Dudhamal T, Mahanta V, Gupta S, Ajmeer A. Topical application of Katupila (Securinega leucopyrus) in Dushta Vrana (chronic wound) showing excellent healing effect: A case study. An International Quarterly Journal of Research in Ayurveda 2014; 35(2): 175. Available from: https://www.ncbi.nlm.nih.gov/pmc/ articles/PMC4279324/.

5. Susruta, Dalhana. Chikitsasthana, dvivraneeyamchikitsitam, Chapter1, Verse8. In: Acharya Jadavaji Trikamji (edi). Susruta Samhita Nibandhasangraha commentary. Reprint 2014. Varanasi: Chaukhambha Orientalia; 2014; 397

6. Soysa P, De Silva IS, Wijayabandara J. Evaluation of antioxidant and antiproliferative activity of Flueggea leucopyrus Willd (katupila). BMC Complementary and Alternative Medicine 2014; 14(1). Available from: https://bmccomplementmedtherapies.biomedcentral. com/articles/10.1186/1472-6882-14-274. 